searching each other's heads and eating the prey there Carver particularly describes the lakes and streams west
of Lake Superior. Lake Winn'pey he spells Winnepeek, of Lake Superior. Lake Winne'peg he spells Winnepeek,
and the Missouri River he speaks of as the Messorie. He relates that it is said that in the country of the Pawnees and beings of both sexes! He also states that a little to the
northwest of the head of the Messorie (Missouri) and St. Pierre (St. Peters) the Indians told him that there was a na-
tion smaller and whiter than the neighboring tribes, who cultivated the ground.

the Rocky Mountains, gold. Further on he speaks prophetically of these moun-
goch tains, of which time has proved much, and says: "These
mountains are more than three thousand miles long. Probably in future ages they may be found to contain more riches in their bowels than those of Industan, Malabar, or are pro
duced from the golden coast of Guinea, nor will I except even the Peruvian mines. West of these mountains future genecountry by the ravages of lawless tyrants, or by religious ences arising from a superabundant increase of inhabitants." Carver mentions a remarkable phenomenon connected with
the straits of Michillimackinack. "In seven and a half years they rise three feet, and the next seven and a half years they decrease three feet." He had

The book contains additional information concerning the origin, customs, etc., of the Indians of the Northwest; also
botanical and gcologicitl information, all interesting.-G. C.
$B$, in Kansas City f.

RECENT PROGRESS IN PHOTOGRAPHY

"ANOTHER revolutionary power in photography," is the heading of an advertisement which appears in some of our
weekly technical journals, and it is this revolutionary power that the exclusive right of its exercise does not appertain to the individual who thus attracts the attention of that portion of the public who are interested in photography. As a
matter of history, it may be as well to mention that several years ago Dr. Míddox obtained sensitive photographic plates by emulsifying bromide of silver in liquid gelatine, coating
glass plates with the product, and then drying the film. He glass plates with the product, and then drying the film. He
was subsequently followed by Mr. Burgess; but not till Mr. Kennett's process was published was anything practicable
for the use of the general public made known. But, notwithstinding Mr. Kennett's fostering care, the gelatinobromide process- as it was incorrectly called-did not make much way, since it appeared to possess but few advantages lodion processes with the nitrate of silver bath, or the newer ones in which bromide of silver was suspended in collodion.
Some two years ago the whole photographic world was
startled by tain pictures in the camera in but a fraction of the time necessary with any process extant up to that time, and he process he used was founded on that of Dr. Maddox, and consisted of bromide of silver in a state of minute subdiviThe rapidity was gained by keeping the gelatine containing the suspended matter in a liquid condition for several days by the prolonged liquefaction. Some idea of the exquisite by the prolonged liquefaction. Some idea of the exquisite
sensibility of bromide of silver can be gathered from the
fact that fact that M. Stas, the great Belgian chemist, while making
his classical researches on the atomic weight of bromide,
found one particular form of found one particular form of this compound which was
speedily blackened by the feeblest yellow light-a light which, as a rule, is totally inoperative to cause the slightest
change in bromide of silver. To revert, however, to Mr. Bennett's process. It was, indeed, a new power placed in
the hands of photographers, and it need scarcely be said that portraitists were not long in adapting it to the requirements of the studio, or, perhaps, to speak more correctly, to adapt
the studio to the requirements of the process. Many of our readers must remember the of ten painfully lcugtty of pose-
perhaps a minute - required from them in the dull days of perhaps a minute - required from them in the dull days of
winter in order to produce a passable likeness. Such a sitting was by the new power reduced to one-sixth of the
lengtll. Eminent experimentahsts on the science side at once grappled with the subject, and by their researches the time of preparation is reduced from days to hours, and in-
creased rapidity is attained; indeed, to such a degree that in some cases a photograph can be taken in from one-thirtieth To these newer plates. then, it is no misnomer to couple the term revolutionary power, and there is no doubt that a re-
volution in some branches of photography has taken place. volution in some branches of photography has taken place.
Photography has known, however, greater revolutions than in the manipulations. Thus calotype, or the waxed paper process, with its development by means of silver, superseded
the daguerreotype, in which the image was developed by mercury vapor; and, again, calotype, in which the founda-
tion was paper, was ousted from its position by Archer's collodion process, in which the paper picture gave way to transparent glass and a substratum of collodion. The diguerreopressed on a metallic silvered plate, and which admitted of
no reproduction in the commercial sense of the word, though it was and is still a glorious work of art, so delicate and it was and is still a glorious work of art, so delicate
rich in detall that nothing can surpass i1. for beauty.

It was not then surprising that any process was bailed
which enabled prints to be made from what is technicall called a negative picture, and calotype fulfilled this condl tion. When Archer introduced the collodion process, how-
ever, its superiority in rapidity and in the beauty of the prints produced from its uegatives, at once gave it a place
which it held till two years ago. The latter have none of the grain of the paper, which in small pictures marred the the daguerrent ype, yet it was a wonderful stride toward as fection. In fact, the collodion processes by the wet or
dry methods rendered photography capable of holding the dry methods rendered photography capable of holding the
place amoug our national industries iwhich it now hold place amoug our national industries iwhich it now holds. emulsion process.
In the recent photographic exhibition in Pall Mall we saw examples of the rapidity of which the gelatine proces 1s capable. A train going 60 miles an hour was fairly ex
pressed on the photographic plate, there being a sharpnes
of image which was truly marvelous. The 1-150th part of a of image which was truly marvelous. The 1.150 th part of a
second is a short interval of time, yet in such a time the

picture was taken. Again, one of the pictorial series of rately placed in a parallel position to the plane of the lens of interest of the year was a series of views on the river the lantern, and against this I rest a sheet of cardboard for
Thames by Mr. Mayland. The silent highway is sparkling focusing, and the sensitive plate afterward. The time of with motion, shipping and steamers at full speed being ren- exposure depends, in the first place, upon the sensitivenes conveyed by the foaming tracks and curling waves which
the size of the enlargement; and, in the second place, upon
tist ilikely ever to exceed Dey make in their passage.
Drawing-room photography by amateurs now becomes Drawing-room photography by amateurs now becomes
possibility and a practicability which before it was not, possibility and a practicability which before it was not,
anterior of a roomarkable picture of the year we have a dark
nte portrait of a charming model secured on one plate in 25 seconds of time. In the old
days such a combination would have been impossible, ex. days such a combination would have been impossible, ex
cept by printing from two or more negatives. Mr. H. P. Robinson, whose artistic work is so well known and so
greatly admired, has thus scored a success in adapting the process to his peculiar style of pictures. In science, how-
ever, the rapid plates have proved of more than yeoman One of the most marvelous feats, bowever, of photo-
graphy is the portrayal of the motion of trotting, cantergraphy is the portrayal of the motion of trotting, canter-
ing and galloping horses by Mr. Muybridge, in America, during minute fractions of a second, and this settles certain points which have long exercised the minds of certain eminent physiologists.
If we quit the

back to the old collodion process, we find that it has also done good service in scientific research. In the Bakerian
Lecture of the Royal Society for the past year, Captain Ab ney has shown how the sensitive compound bromide of sil-
ver can be so modified as to cause radiations of very low wave-length to impress themselves on the photographic plate, and in a miap he gives the Fraunhofer lines which
exist in the solar spectrum far down below the visible red rays of the spectrum. In the prints as usually supplied, the gradually fade and become worthless.
The simplification of the Woodburytype process, and of printing in printing ink from gelatine surfaces, is still mak
ng progress, as evinced by the number of specimens of each which we see in books of travels, or of transactions of ant

\section{ENLARGING BY THE GELATINE PROCESS} By H. J. Palmer.

AT this time of the year the photographic opportunitie most of us-as amateurs-are of necessity very limite
their character; but the production of enlarged copies maller negatives taken during the past season is an employ ment for a winter's evening full

The gelatine process enables us to practice the art of en
The of means. For, with a sciopticon-or, indeed, with any triplex paraftine lamp-an enlargement on a gelatine plate of the largest size, and composed of a slow-but-sure emulsion, regard to cost, a plate $: 0$ by 15 may be sensitized with a gel bouts; and the mode of procedure is simplicity itself. I will give a brief account of the preparation of a plate I used an emulsion consisting of 20 grains of gelatine, 13
grains of silver, and 8 grains of bromide of ammonia to the
ounce. This was prepared in the evening in a concentrated form, $i$. $e$., with half the necessary amount of water, and placed on the bottom or warmest shelf of the drying cup-
board, in close proximity to the opening at the apex of an board, in close proximity to the opening at the apex of an
iron cone, with a small gas burner below. Having been left all night to cook, in the evening it was poured out into a
porcelain dish, placed und $r$ a dipping tap of cold water till business hours were over in the evening, and then, af te training and warming, it was poured through glass wool into the porcelain cup of a child's food warmer, and the whole
brought up to its full quantity by addition of alcohol and ater in equal proportions.

A plate was now made comfortably hot at the fire, and placed on the open palm of the left hand. Three ounces of ing glass, were poured on to the center of the plate in a poo
of circular shape, and even distribution over the surface was effected by means of the fingers of the right hand. No
eflass rod or contrivance of any kind that I have met with glass rod or contrivance of any kind that I have met with
can compare with the fingers and hand as distributers of recommend their employment for this purpose if they have been recently in contact with the hyposulphite, or, indeed, of gelatine sets very speedily, and therefore as little delay a possible was employed before the plate was deposited on the
leveled shelf. I have noticed that there is a considerable difference between the rapidity of setting of gelatine of
various makes. Nelson's photographic gelatine sets more quickly than the opaque, and the French Coignet is the
slowest of all. I recommend this last, then, as the prefer. I recommend this last, the
able kind for sensitizing plates of large size.

The crux of the gelatine process for amateur makers of
plates lies in the drying. A small plate can easily receive an plates lies in the drying. A small plate can easily receive an
alcoliol bath, and so be speedily ready for exposure; but that is not so practicable with a film of large dimensions. The that it removes all varnish from the wooden trays in which it is applied to plates of large size, and porcelain trays are The great secret of success in coating plates of consider-
able size rests with the amount of emulsion poured, in the able size rests with the amount of emulsion poured, in the
first instance, upon the surface to be covered. If this quan. tirst instance, upon the surface to be covered. If this quan. over the whole of the plate, and the result will be misery
and mess. I mentioned three ounces just now as the quanand mess. I mentioned three ounces just now as the quan-
tity necessary for a 15 by 20 plale; but it will be found far
better to have courage to pour much more than this upon the warm surface first, and, after flowing it nicely around the
edges and corners in succession, to return the surplus to the edges and corners in succession, to return the surplus to the
vessel. This, I think, is the secret of successful coating of plates of all sizes-to have the courage to pour a plentiful
pool of emulsion at the first. I recommend the palm of the hand as the best plate holder; for I have never yet met with keep a firm grasp upon its plate until coating was com There is no need of apparatus of any kind beyond an ordinary lantern, and a transparency for the production of
gelatine enlargement. I usually employ a plate box accuthe size of the enlargement. It is not likely ever to exceed
ten minutes, though it may be modified also by the density
or thinness of the transparency employed. It should be
borne in mind, in connection with this subject of enlarging y the gelatine process, that small negatives which are worth
ess for printing, from over exposure, are often capable of prorlueing very fine positives with the lantern. And nothatc when rightly exposed and developed with ferrous

\section{ON THE PREPARATION OF GELATINE}

A the suggestion of the Hon. Secretary of the Mancheser Photographic Society to explain the working of my in and having made some observations relative to the prepar tion of emulsions, I have been asked to put together, if pos sible, the remarks I made at that time. I now make the
attempt, and I hope what I may say will help a little. The injector exhibited was a ten-nunce one, consisting of a small
bottle, an intermediate stopper, and a larger bottle. I will now give my process of making emulsion, using the parts now give my process of making emulsion, using the parts
of the injector to illustrate my mode of working.
Into the smaller bottle I put 150 grains of nitrate of stlver dissolved in six drachms of water. I then add by de-
grees liquid ammonia (880) until the oxide of silver formed grees liquid ammonia (880) until the oxide of silver formed
is redissolved and the solution bright. In the larger bottle is redissolved and the solution bright. In the larger bottle
I place 30 grains of gelatine, 100 grains bromide of ammonium, and 5 ounces of water. After standing for a short their contents to a moderate temperature. The concave end of the stopper must now be placed upon the smaller bottle,
then inverted into the larger bottle. The combined bottles are now grasped by the right hand, with the thumb pressed
firmly upon the upper bottle and in that position is agitated by percussion either upon the palm of the other hand or otherwise on a pad formed out of a handkerchief rolled
up, ball shaped, until the silver solution is injected. A up, ball shaped, until the silver solution is injected. A ing silver; then inject as before. It is important that the rubber rings are kept round the stopper to prevent jamming
of stopper and bottles. Place the emulsion in a cool place to set; when in that
condition break up the mass into small particles by means
of a thin glass rod, filling the bottle with water at the same time. When it has settled pour the excess of water off; re
peat the operation three or four times, and finally tie a ece of fine muslin over the neck. Then invert the bottle
drain upon a thick pad of blotting-paper (which latter,

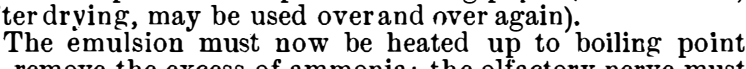
to remove the excess of ammonia; the olfactory nerve must Wety up to 10 ounces, and then add the remainder of the gela-
titan must be heated until the gelatine is perfectly dissolved. The funnel plugged with wool; it is then ready for use. Why I use so small a quantity of gelatine is that I con-
. sider the sensitive germ of emulsion is as fully secured
in the small quantity as in using the full quantity; and a!so, if the perfect removal of the soluble salt from the mulsified gelatine assists in conferring greater sensitive-
ness, you are more likely to secure that end by dealing ness, you are more likely to secure that end by dealing
with as little gelatine as possible in the first instance.
There is no doubt the sensitiveness of a geiatine film de ver, so to speak, just in the same way that Fothergill plates are prepared. By pouring albumen upon a par.
py which is considered to be due to the formation of albumi-

nate of silver.
My arrangement for warming the emulsion is by the usual which I make serve two purposes-a light to work by, and the waste heat I utilize by placing at the top a hemispherical dish of colper, which $\mathrm{I}$ find most convenient for warm-
ing the emulsion dish and contents. The next matter is measuring the emulsion for each size
f perate. The spon or ladle system of measuring I consider defective. As the emulsion requires to be stirred oc-
casionally. it is impossible to do so without bringing about casionally. it is impossible to do so without bringing about
the "bubble" reputation, which is not very desirable, nor
can it be avoided altogether; moreover they cannot well be can it be avoided altogether; moreover they cannot well be use of a graduated glass syringe about the best for the pur-
pose. There are two kinds of syringe known to the trade pose. There are two kinds of syringe known to the trade
as "male" and "female." The latter is the preferable one.
It has a rounded end with a number of perforations in it; is a most useful appliance; it naay be used as a stirrer; takes whatever, if taken from the lower stratum of emulsion; it is ROBERT KNOTT.

\section{GELATINE BROMIDE TISSUE.}

We have read several accounts of trials to make flexible t. would be indeed very important to have such a tissue, which would make the practice of photography much less with Warnerke's collodio-emulsion films, but, for some reason, this ingenious product has not come into general use.
Although the preparation of the collodio-bromide tissue is probably a difficult matter, it is our opinion that the prepa. ration of gelatine bromide paper should be much easier. Everybody knows how carbon paper is prepared, a sheet of
paper being drawn over the surface of a warm gelatine solution contilining pigment; exactly in the same manner a band of paper could be coated with a gelatine solution containing
bromide of silver. Warnerke gave Jis paper preliminary bromide of silver. Warnerke gave lis paper preliminary
catings of India-rubber and plain collodion, and perhaps a
imilar preparation would be necessary for the gelatine

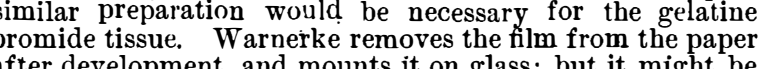
after development, and mounts it on glass; but it might be more convenient to let it dry on the paper, and tlfen to render it transparent by means of wax or a suitable varnish. or making positive prints on a large scale by means of

* A communication to the Manchester Photographic Society. 